\title{
Assessment of Forest Cover Change of Dang, an Inner Terai District of Nepal
}

\author{
Yam Bahadur K.C. ${ }^{1}$ \\ Institute of Forestry, Tribhuvan University,Hetauda, Nepal, \\ ${ }^{*}$ Corresponding author:: ykc@iofhc.edu.np.
}

\section{Abstract}

This study analyzed the dynamics of changes of forest cover classes in the inner Terai District Dang, Nepal, based on Landsat Thematic Mapper (TM) images from two different years, viz., 1990 and 2011. Forest cover change analysis was performed through the analysis of a classified Landsat TM image using supervised classification. The overall classification accuracy for seven different land cover classes considered in this study were $80.37 \%$ and $80.56 \%$ for years 1990 and 2011 , respectively. These classified images were further reclassified as forest and non-forest to analyze forest cover dynamics effectively using the post classification change detection. The results indicated that during 1990-2011, the total spatial areal coverage of forest land converted into other land cover was 20612 ha (shrubland), 8571 ha (agriculture), and 2787 ha (others) non-forest classes. A significant portion of non-forest classes was also converted into forest (e.g., 11433 ha of shrubland, 5663 ha of agriculture, and 5581 ha of other non forest classes). Sand and water bodies remained more or less constant during this period. While forest cover was estimated to be disappearing at the rate of $0.2 \%$ per year, dense forest appears to be converting into a sparse forest at the rate of $0.1 \%$ per year. Future study to assess the causes and driving forces of forest cover change in Nepal should get guidance from this study on where to target interventions.

Key words: Forest cover, landsat TM, land cover classification and change detection

\section{Introduction}

Today forests cover about one-third of the Earth's land surface and provide a range of ecosystem services necessary to human survival like maintenance of biological diversity, regulation of climate and purification of air and water. Forests, however, are primary targets in many countries for agricultural and urban expansion. The world's forests, especially, tropical forests, are cleared, degraded and fragmented by timber harvest, conversion to agriculture, road building, human caused fire, and other human activities. The world wide deforestation continues at an alarmingly high rate: 16 million ha per year (FAO, 2015). In Asia a net loss of about 0.6 million hectares per year occurred in the 1990s; however, from 2000 to 2010 a net gain of more than 2.2 million hectares per year was reported, primarily due to large-scale afforestation efforts, particularly in China, but yet high rates of net loss continued in many countries in South and Southeast Asia (FAO, 2015). The changing of forest covers in general and of tropical forests in particular has a severe long term environmental and socioeconomic effect globally as well as locally. Major environmental problems caused by forest cover change are global climate change, habitat degradation, species extinction (Goldsmith, 1998).

Nepal has 5.96 million ha of forests, representing $40.36 \%$ of its land area (FRA, 2014). About $17 \%$ area of Nepal is covered by the Terai districts within subtropical to tropical eco-climatic zone. It possesses 
most productive agricultural land of Nepal, and has relatively large blocks of high value Shorea robusta forests (NBS, 2002). Terai supports ecosystem diversity, provides habitat for mega-endangered species such as tigers, rhinos and crocodiles, harbors important wetlands and provides important economic benefits to the country. On the other hand, high population growth, unmanaged settlement, unemployment, encroachment, grazing and forest fire are some of the underlying causes of the reduction of forest resources. Brampton and Cammaert (2007) suggest that Terai forests have a higher deforestation rate than the middle hill forests of Nepal, partly because of the higher value of their timber. A study in 20 Terai districts showed forest cover loss with annual rate of $0.6 \%$ between 1990 and 2000 (DoF, 2005). According to a recent forest assessment report, the forest area in the Terai decreased by 16500 ha with annual rate of $0.44 \%$ between 2001 and 2011 (FRA, 2014). This situation proves that there is still a good deal of pressure on forests especially on those in the Inner Terai and Terai. Despite the success of community forestry in the hills, Nepal still lacks an effective forest governance mechanism in the Terai. The Terai forests are highly controversial due to their complexity, geopolitical context and controversies over government policies. The largest segments of Terai forests are still under the control of government and are without effective management interventions. Such forests are suffering from heavy deforestation and degradation. In this regard, it is important to monitor the forest cover dynamics in Terai to effectively manage the forests in Terai. Areas that are rapidly deforested require immediate attention from the governing body, local people and conservationists.

Advanced technology, such Geographical Information System (GIS) and remote sensing, which emerged in early 1970s, is vital to the world, particularly to environmental scientists (Jayanth et al., 2015). Recently, many researchers (Baumann et al., 2014; Butt et al., 2015; Chasmer et al., 2014; Churches et al., 2014; Dronova et al., 2015; Iqbal and Khan, 2014; Naqvi et al., 2014, Zhang et al., 2013) have used remote-sensing data to classify land-use, monitor land use, manage land degradation and quantify and analyze land-use changes. Landsat data are also used to investigate land degradation, such as desertification and deforestation. Remote sensing and GIS studies of environmental degradation are more effective than field surveys in terms of cost, time, and area coverage (El Baroudy and Moghanm, 2014). Today, many different scientific approaches, together with remotely sensed satellite images and GIS, play important roles in analyzing and monitoring land-cover change based on time series (Huang and Siegert, 2006; Jayanth et al., 2015; Rawat et al., 2015; Yiran et al., 2012). Moreover, a wealth of Landsat imagery is now freely available to the scientific public through the United States Geological survey (USGS) site. This cost effective approach will help policy makers and land managers to react timely and focus efforts on managing the forests. Considering the geography of Nepal, remote-sensing methods can play a significant role in providing information about forest conditions. 
Therefore, the present study was designed to develop a monitoring scheme for operational use to assess, map and evaluate forest cover change for sustainable management. The study was carried out in the inner Terai, Dang district of Nepal. The outcome of the study aimed to support policy makers and resource managers with useful information about where the immediate deforestation mitigation actions were required.

\section{Materials and Methods}

\section{Study Area}

Dang district (Fig. 1) is an inner Terai district of Nepal, which borders India to the south. It is located between $8202^{\prime}$ and $8205^{\prime} \mathrm{E}$ longitudes and $2802^{\prime} 9^{\prime}$ and $28036^{\prime} \mathrm{N}$ latitudes and covers an area of 2902.510 square kilometers, with an elevation ranging from 213 to $2058 \mathrm{~m}$ above sea level. It is accessible from the east-west highway, and numerous feeder roads connecting the villages to the town. The total human population of the district is 552583 (CBS, 2012). The annual precipitation varies from 1584 to $2287 \mathrm{~mm}$ with an annual mean of $1830 \mathrm{~mm}$. The study area enjoys nearly tropical and subtropical climate. Forests cover over $50 \%$ of the area while the remaining area falls under agriculture, water body and others. Dang district is geographically divided into two parts: Siwalik-hills and the plain valley or Bhabar. It is bound by the Mahabharat hills on the north and outer Siwalik hills on the south. The soil in the hills is loosely bound coarse sand, gravel and conglomerates while it is clay and sandy loam in Dang and Deukhari valley.

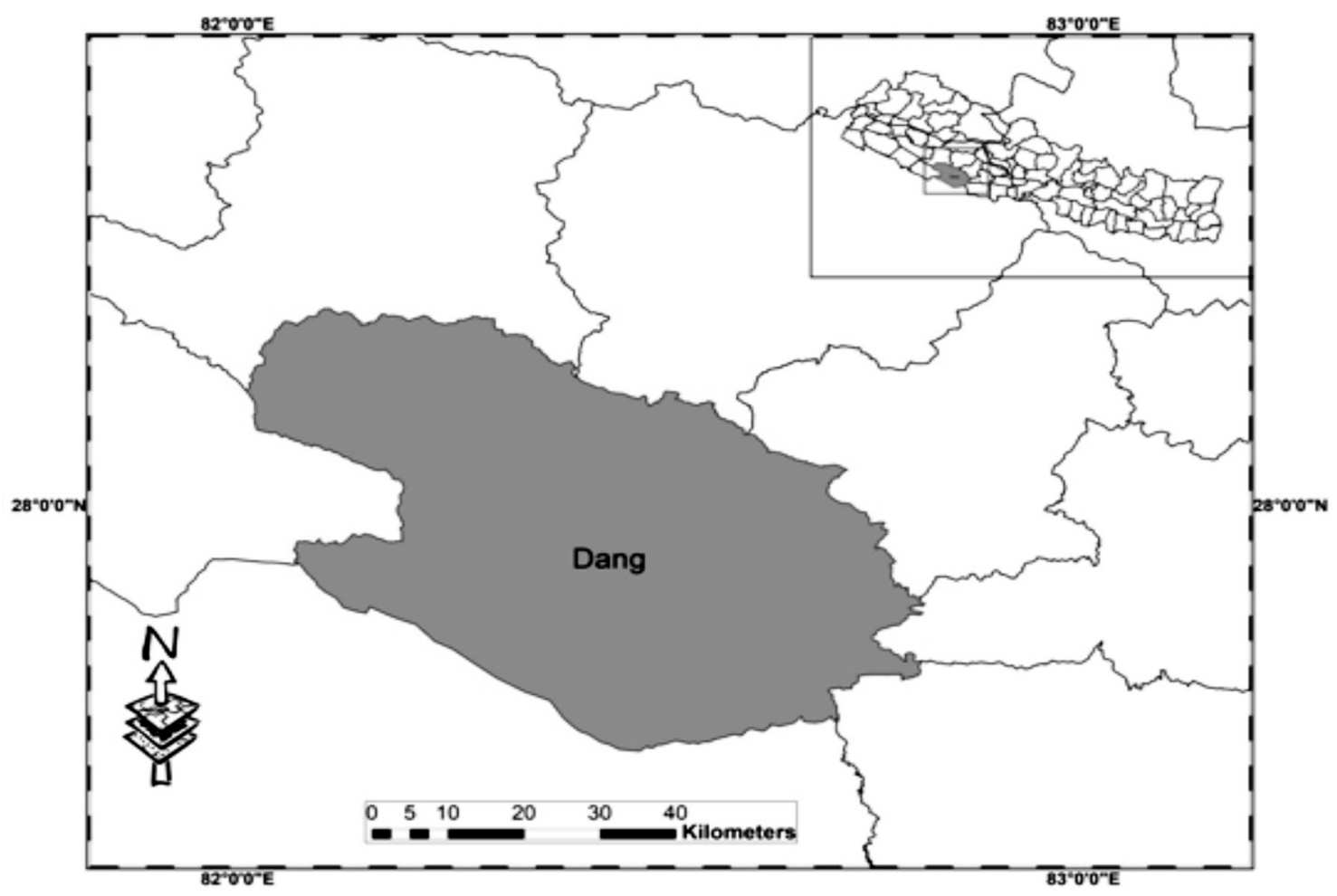

Figure 1: Geographical location of the study area. 


\section{Database preparation}

Landsat Thematic Mapper (TM) at a resolution of $30 \mathrm{~m}$ of 1990 and 2011 was used for land use/cover classification (Table 1). The satellite data covering study area were obtained from the USGS Global Visual Viewer (Source: http://glovis.usgs. gov). The data were selected based on availability of cloud free satellite scenes during the study period.
These data sets were imported in ERDAS Imagine version 9.3 (Leica Geosystems, Atlanta, U.S.A.), satellite image processing software to create a false colour composite (FCC). The layer stack option in image interpreter tool box was used to generate FCCs for the study areas. The sub-setting of satellite images was performed for extracting study area from both images by taking geo-referenced out line boundary of Dang district map as AOI (Area of Interest).

Table 1: Satellite imagery and its specifications

\begin{tabular}{cccccc}
\hline Path/row & Spatial resolution & Band & Acquisition Date & Spacecraft & Sensor \\
\hline $143 / 41$ & $30 \mathrm{~m}$ & $1-5,7$ & $17-11-1990$ & Landsat $4-5$ & TM \\
\hline $143 / 41$ & $30 \mathrm{~m}$ & $1-5,7$ & $26-10-2011$ & Landsat $4-5$ & TM \\
\hline
\end{tabular}

\section{Image Classification}

A supervised image classification method was used to classify the satellite imagery into different land use/cover land use classes. Maximum likelihood algorithm (MLC) is one of the most popular supervised classification methods used with remote sensing image data (Churches et al., 2014). This method is based on the probability that a pixel belongs to a particular class. The basic theory assumes that these probabilities are equal for all classes and that the input bands have normal distributions. However, this method needs long time of computation, relies heavily on a normal distribution of the data in each input band and tends to over-classify signatures with relatively large values in the covariance matrix. The spectral distance method calculates the spectral distance between the measurement vector for the candidate pixel and the mean vector for each signature and the equation for classifying by spectral distance is based on the equation for Euclidean distance. It requires the least computational time among other supervised methods; however, the pixels that should not be unclassified become classified, and it does not consider class variability. Ground verification was done for doubtful areas. Based on ground truthing, the misclassified areas were corrected using recode option in ERDAS Imagine. The error matrix and Kappa statistics methods were used to assess the mapping accuracy. For land cover classification, there are seven land cover classes identified in the study area, which are dense forest, sparse forest, agriculture, shrub land, sand and gravel, water body and others. The classes are used to identify forest cover change process in the study area. The forest includes all the area covered by woody vegetation with over $10 \%$ (FAO, 2000). Description of land cover classes is as follows (Table 2). 
Table 2: Descriptions of land cover classes

\begin{tabular}{ll}
\hline \multicolumn{1}{c}{ Land cover lasses } & \multicolumn{1}{c}{ Description } \\
\hline Dense forest & Areas with trees with $>40 \%$ crown cover \\
\hline Sparse forest & Areas with sparsely distributed trees by $10-40 \%$ crown cover \\
\hline Agriculture & Agriculture areas both currently cultivated and fallow lands \\
\hline Shrub land & Areas with $<10 \%$ crown cover dominated by shrubs, along with grassland \\
\hline Sand and gravel & often distributed near or mixed with shrubs \\
\hline Water bodies & Areas with sand and gravel deposits along river banks \\
\hline Others & Areas that are not included in any of the above classes and mainly comprise \\
\hline
\end{tabular}

\section{Change Detection and Analysis}

For performing land use/cover change detection, post-classification comparison detection method by image overlay was applied. A pixel based comparison was used to produce change information on pixel basis and thus, to interpret the change efficiently taking the advantage of 'fromto' information. Accordingly, the classified image of two different years was compared using cross- tabulation in order to determine qualitative and quantitative aspects of the changes for the periods from 1990 to 2011. A change matrix (Weng, 2001) was produced with the help of ERDAS Imagine software. Quantitative areal data of the overall land use/cover changes as well as gains and losses in each category between 1990 and 2011 were then extracted.

\section{Results and Discussion}

\section{Land Use/Cover Status}

Accuracy assessment of the land use/cover classification results obtained showed an overall accuracy of $80.37 \%$ for 1990 and $80.56 \%$ for 2011 . The Kappa coefficients for 1990 and 2011 maps were 0.7675 and 0.7661 respectively. Fig. 2 (a) depicts spatial distributional pattern of land use/cover of Dang district for the year 1990 while Fig. 2(b) for the year 2011. These data reveal that in 1990 , about $52.86 \%(1,53,439.14$ ha $)$ area of Dang district was under forest, $10.02 \%$ $(29,091.51 \mathrm{ha})$ under shrub land, $18.09 \%$ $(52,507.00 \mathrm{ha})$ under agriculture, $15.72 \%$ $(45,636.57 \mathrm{ha})$ under others, $3 \%(8,707.08$ ha) under sand and gravel, and $0.3 \%(869.43$ ha) under water body. During 2011 about $49.68 \%(1,44,197.97 \mathrm{ha})$ area of dang district was under forest, $14.78 \%(42,910.61 \mathrm{ha})$ under shrub land, $18.07 \%(52,440.48 \mathrm{ha})$ under agriculture, $14.06 \%(40,818.41 \mathrm{ha})$ under others, $3.11 \%(9,031.96$ ha) under sand and gravel, and $0.29 \%$ (851.32 ha) under water body (Table 3).

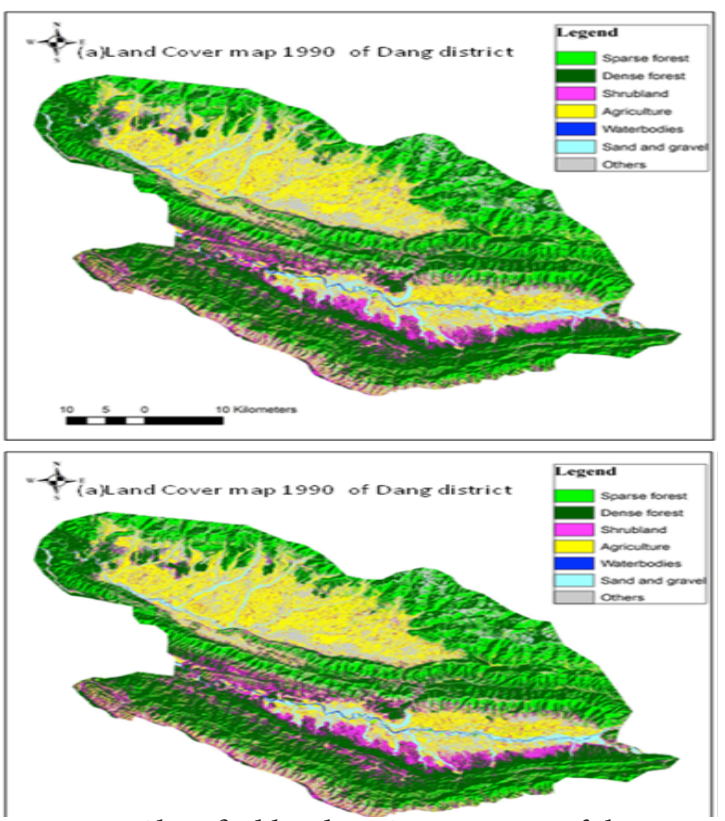

Figure 2: Classified land use/cover status of the Dang district; (a) in 1990, (b) in 2011. 
Land Use/Cover Change

Data registered in Table 3 and Fig, 3 reveal that both positive and negative changes occurred in the land use/cover pattern of the Dang district. During the period (19902011)

\section{Land use/cover Change(1990-2011)}

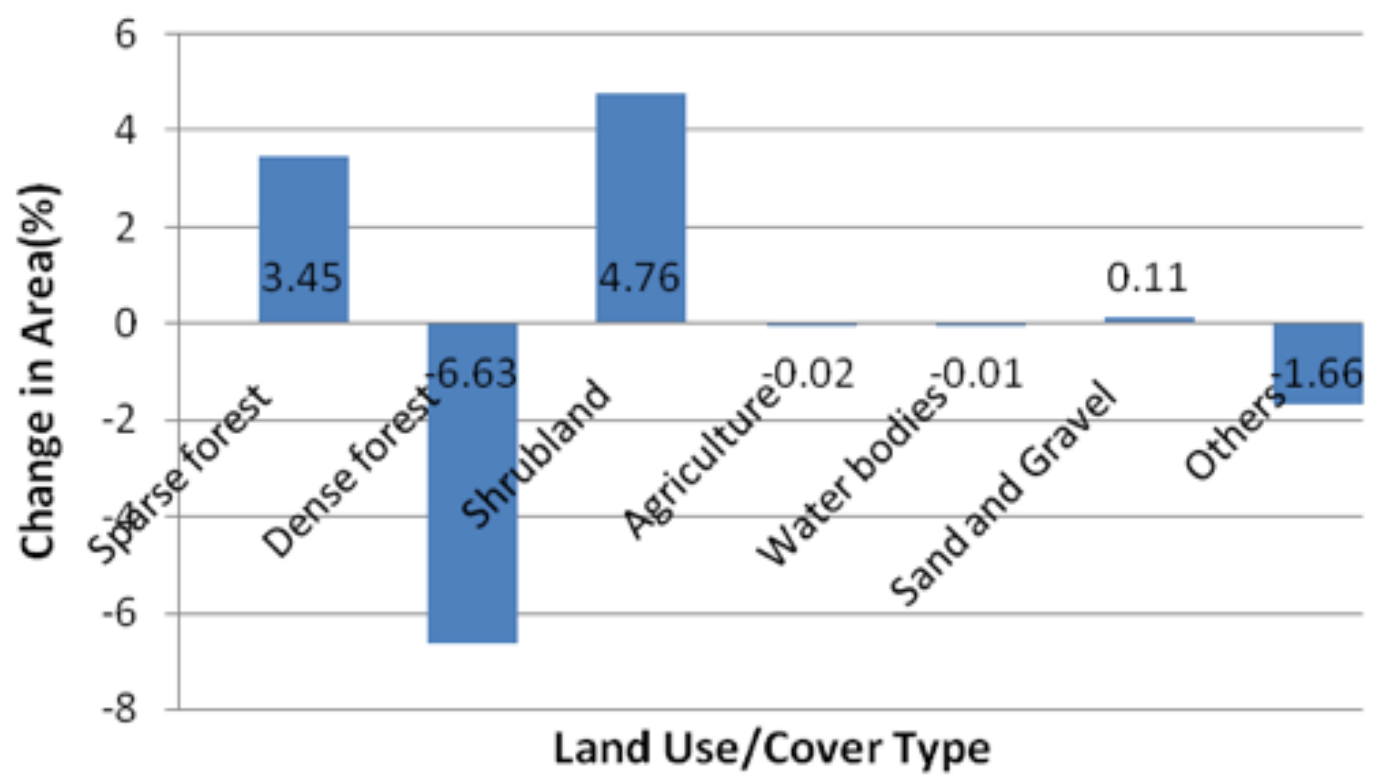

Figure 3: Land covers dynamics between 1990 and 2011.

Table 3: Areal extent of land covers land use (1990 -2011). Negative number indicates area lost.

\begin{tabular}{lllll}
\hline Land cover & \multicolumn{1}{c}{$\begin{array}{c}\text { Area (ha) } \\
\mathbf{1 9 9 0}\end{array}$} & $\begin{array}{c}\text { Area (ha) } \\
\mathbf{2 0 1 1}\end{array}$ & $\begin{array}{c}\text { Change } \\
\mathbf{( \% )}\end{array}$ & $\begin{array}{c}\text { Difference } \\
\text { (ha) }\end{array}$ \\
\hline Sparse forest & $47,737.8$ & $57,753.91$ & 3.45 & $10,016.11$ \\
\hline Dense forest & $1,05,701.3$ & $86,444.06$ & -6.63 & $-19,257.28$ \\
\hline Shrubland & $29,091.51$ & $42,910.61$ & 4.76 & $13,819.1$ \\
\hline Agriculture & 52,507 & $52,440.48$ & -0.02 & -66.52 \\
\hline Water bodies & 869.43 & 851.32 & -0.01 & -18.11 \\
\hline Sand and Gravel & $8,707.08$ & $9,031.96$ & 0.11 & $-4,818.16$ \\
\hline Others & $45,636.57$ & $40,818.41$ & -1.66 & \\
\hline Total & $2,90,251$ & $2,90,251$ & & \\
\hline
\end{tabular}


Table 4: Change area matrix of land use/cover change (1990 -2011).

\begin{tabular}{|c|c|c|c|c|c|c|c|c|}
\hline Class & $\begin{array}{c}\text { Sparse } \\
\text { forest }\end{array}$ & $\begin{array}{l}\text { Dense } \\
\text { forest }\end{array}$ & $\begin{array}{l}\text { Shrub } \\
\text { land }\end{array}$ & $\begin{array}{l}\text { Agricul- } \\
\text { ture }\end{array}$ & $\begin{array}{l}\text { Water } \\
\text { bodies }\end{array}$ & $\begin{array}{c}\text { Sand } \\
\text { and } \\
\text { Gravel }\end{array}$ & Others & $\begin{array}{c}\text { Total } \\
\text { area (ha) } \\
1990\end{array}$ \\
\hline $\begin{array}{l}\text { Sparse } \\
\text { forest }\end{array}$ & $30,962.30$ & $14,252.10$ & $3,155.51$ & $4,281.53$ & 6.58 & 180.32 & $4,915.57$ & $57,753.90$ \\
\hline $\begin{array}{l}\text { Dense } \\
\text { forest }\end{array}$ & $5,217.27$ & $70,834.70$ & $8,277.40$ & $1,381.47$ & 5.77 & 62.06 & 665.40 & $86,444.10$ \\
\hline Shrub land & $5,010.53$ & $15,601.50$ & $11,155.40$ & $5,220.57$ & 52.47 & 709.18 & $5,161.96$ & $42,910.60$ \\
\hline Agriculture & $1,909.11$ & 878.45 & $2,990.79$ & $23,907.40$ & 267.80 & $3,449.63$ & $19,037.30$ & $52,440.50$ \\
\hline $\begin{array}{l}\text { Water } \\
\text { bodies }\end{array}$ & 9.42 & 7.15 & 13.97 & 94.87 & 248.39 & 314.58 & 162.94 & 851.32 \\
\hline $\begin{array}{l}\text { Sand } \\
\text { and Gravel }\end{array}$ & 88.11 & 97.39 & 236.20 & $3,271.26$ & 59.54 & $1,733.75$ & $3,545.71$ & $9,031.96$ \\
\hline Others & $4,541.05$ & $4,030.06$ & $3,262.24$ & $14,349.90$ & 228.89 & $2,257.57$ & $12,148.70$ & $40,818.40$ \\
\hline $\begin{array}{l}\text { Total area } \\
\text { (ha) } 2011\end{array}$ & $47,737.80$ & $1,05,701$ & $29,091.50$ & 52,507 & 869.43 & $8,707.08$ & $45,637.60$ & $2,90,251$ \\
\hline
\end{tabular}

The forest coverage including dense and sparse forest in the study area has decreased from $1,53,439$ ha in 1990 to $1,44,198$ ha in 2011 , which is $3.18 \%$ of the total study area. The shrubland has increased from 29,091 ha in 1990 to 42,910 ha in 2011 , which is $4.76 \%$. The agriculture has decreased from 52,507 ha in 1990 to 52,440 ha in 2011 , which is $0.02 \%$. The other areas have decreased from 45,636 ha in 1990 to 40,818 ha in 2011 , that is, $1.66 \%$. Sand and gravel area has increased from 8,707 ha in 1990 to 9,031 ha in 2011, that is, $0.1 \%$. The water body of the study area has decreased from 869 ha in 1990 to 851 ha in 2011, which also is $0.01 \%$.

Table 4 reveals the change area matrix of land use cover (1990-2011). It demonstrates the quantity and quality of land cover changes, particularly "from-to" information, which occurred from 1990 to 2011 within the study area. The diagonal of this table shows the land use land cover proportions that remained unchanged from 1990 to 2011. A total forest area of 32,173 ha was converted into other land use land cover classes, representing about $20.97 \%$ of the district forest (Table 4). The most common land cover change was occurring in the form of a shift from dense forest to shrubland (15,601 ha), sparse forest to shrubland (5,011 ha) (Table 4), and mainly located in the South Eastern part of the district (Fig. 4), followed by forests (sparse and dense forest) to others $(8,571 \mathrm{ha})$, and forest to agriculture (2,787 ha) respectively. Similarly, about 14,252 ha dense forests shifted into sparse forest. While only 5,217 ha sparse forest converted into dense forest. On the other hand, shrubland to forest $(11,433 \mathrm{ha})$ and others to forest (5,581 ha) and agriculture to forest (5663 ha) respectively was the most common type of land use land cover class conversion, covering about 22,932 ha (Table 4). These detected areas are mostly located at the border of the district (Fig. 4). The unchanged forest represents $1,01,797$ ha $(66.34 \%)$ while unchanged nonforest comprises 49,194 ha $(35.9 \%)$. 
Forest Covers Change Analysis (1990-2011)

In order to analyze forest cover change, the already classified land cover data were reclassified into dense forest, sparse forest, and non-forest areas. Non-forest areas include all land cover classes except dense forest and sparse forest, i.e. agriculture, shrubland, sand and gravel, water bodies and others. Dense forest and sparse forest were reclassified as forest. The forest cover change classification scheme is shown in Table 5. Based on that aggregation, a change detection analysis was performed in order to detect the specific forest change. The change from forest to non-forest is classified as deforested area, while change from non-forest to forest is considered a new forest area. The change from dense forest to sparse forest is labeled as degraded area, while change from sparse to dense is named improved forest.

Table 5: Forest cover change classification scheme.

\begin{tabular}{lll} 
First class & Second class & FC change class \\
\hline Sparse forest & Dense forest & Improved forest \\
\hline Non forest & Forest & Degraded area \\
\hline Dense forest & Sparse forest & New forest area \\
\hline Forest & Non forest & Deforested area \\
\hline Forest & Forest & No change \\
\hline Non forest & Non forest & No change \\
\hline
\end{tabular}

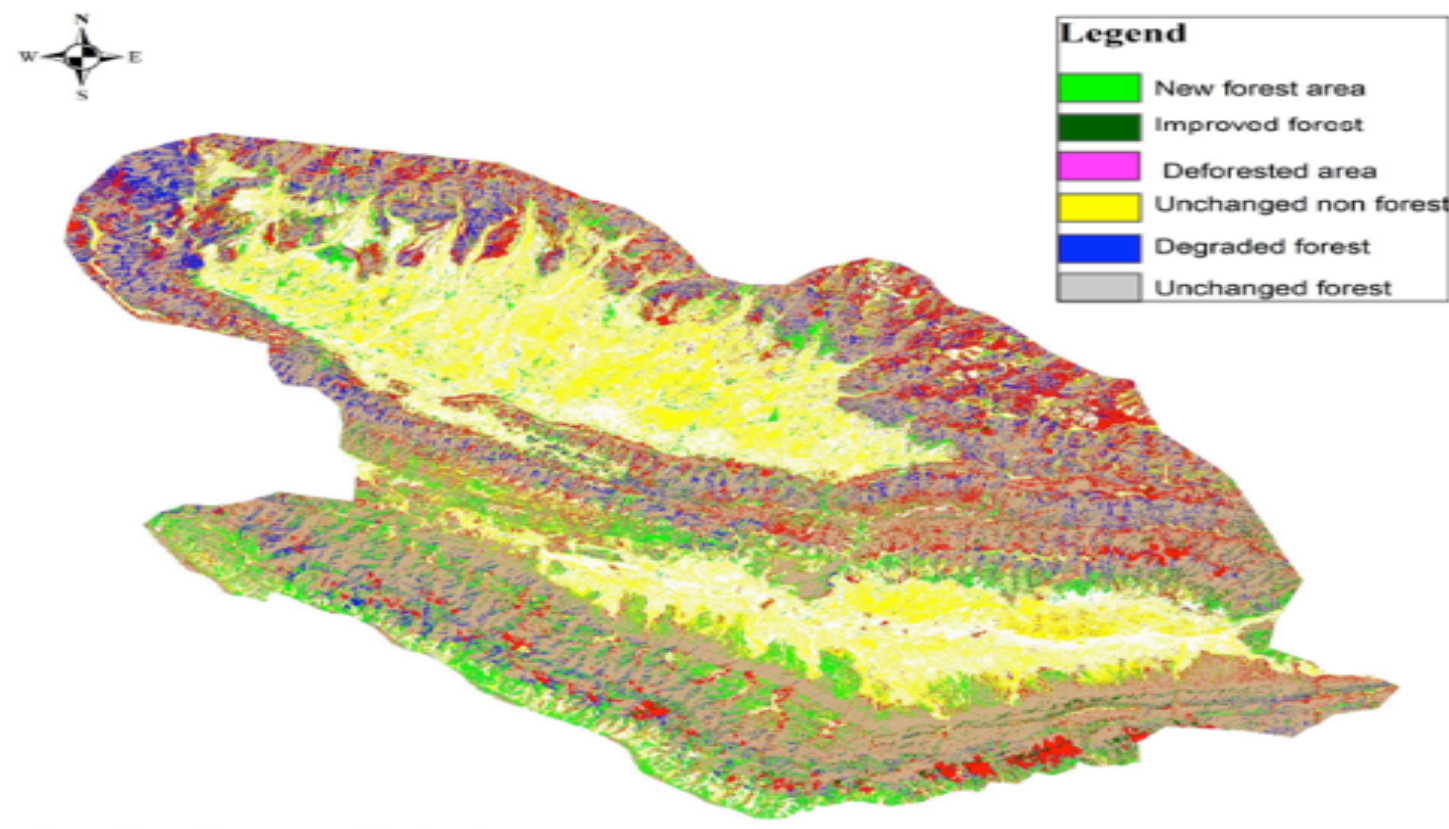

Figure 4: Forest cover change in the Dang district (1990-2011). 
It can be seen from Table 6 that within the study area about 5,217 ha (i.e. $10.93 \%$ sparse forest in 1990) show improvement in terms of forest cover change and 22,932 ha (i.e. $16.76 \%$ of non forest area in 1990) were afforested during 1990-2011. The amount by which dense forest was changed into the sparse forest (i.e.14,252 ha) was considered as degraded forest area and the amount by which forest area was changed into nonforest area (i.e. 32,173 ha) was deforested area. About 1,01,797 ha (66.34\%) remained unchanged forest and 49,194 ha (35.56\%) remained unchanged non-forest.

Table 6: Change area matrix results for forest cover change (1990-2011).

\begin{tabular}{|c|c|c|c|c|c|}
\hline \multirow[t]{2}{*}{ Land cover } & \multirow{2}{*}{$\begin{array}{l}\text { Area(ha) } \\
1990\end{array}$} & \multicolumn{4}{|c|}{ Forest cover change (ha) } \\
\hline & & Improved forest & New forest area & Degraded area & Deforested area \\
\hline Sparse Forest & $47,737.8$ & $5,217.27$ & & & \\
\hline Non forest & $1,36,811.6$ & & & & \\
\hline Dense forest & $1,05,701.34$ & & $14,252.1$ & & \\
\hline Forest & $1,53,439.14$ & & & & $32,172.77$ \\
\hline Change (\%) & & 10.93 & 13.48 & & 20.97 \\
\hline $\begin{array}{l}\text { Rate of change }(\% \text { per } \\
\text { year })\end{array}$ & & 0.55 & 0.67 & & 1.05 \\
\hline
\end{tabular}

In the study area, during 1990-2011 the amount of forest area which increased $(22,932 \mathrm{ha})$ was found to be significantly lower than the amount of forest area that was lost (32,173 ha). In addition, the amount by which dense forest has changed to sparse forest $(14,252$ ha) is larger than the amount by which sparse forest has changed to dense forest $(5,217 \mathrm{ha})$ (Table 6). Overall, the net rate of conversion of forest to non-forest was $0.21 \%$ per year. Similarly, the net rate of conversion of sparse forest to dense forest was found to be $0.12 \%$ per year (fig. 4 and table 6). Similar results have been reported by DoF (2005), where the forest loss/decrease per year in Nepal for different time series was found to comprise $0.2 \%$ (1978-1986), 0.8\% (19861994), $0.5 \%$ (1978-1994), $0.5 \%$ (1994$2005)$ and $0.06 \%$ (1991-2005) respectively. The highest rate of change occurred during 1986-1994 and lower during 1991-2001. However, the study of DoF (2005) covered data from 20 Terai districts to analyze the forest cover change from 1991 to 2001.

The main factors that caused land cover change from forest to non-forest seem to be driven by population growth, forest encroachment, illegal logging, grazing and forest fire. The population has almost increased from 4,62,380 (2002) to 5,52,583 (2012) (CBS, 2012). The forces behind the forest cover change can be partly linked to population pressure as well as to increased demand of forest products such as fuel wood, building poles and making furniture as well as to obtain agricultural lands. More specifically, the majority of people in Dang district also depend on fuel wood as a source of energy. In addition, between the year 1963 and 2012 about 2,393 ha of forest cover was encroached with settlement expansion. Hence, the forest encroachment is considered to be one cause of forest cover changes in the district. One of the most important reasons for forest encroachment is related to the civil war in the country from 1996 until 2006 (DFSP, 2012). The 
change in non-forest to forest land cover is likely due to afforestation or reforestation. Afforestation is achieved through either plantation or natural regeneration. Under the community forestry program, the user groups take responsibility for managing and monitoring forest areas according to a management plan, which includes measures for fuel wood, timber and fodder extraction on an equitable basis. This is aided by the natural conditions, which support natural regeneration. An important point in this respect is the control of livestock grazing in community forests and the promotion of stall-feeding, which has a remarkable positive impact on vegetation cover. Thus, the non forest to forest land cover change in the study area seems to be mainly supported by natural regeneration and protection due to the positive influence of the community forestry program on the forest cover in the area along with financial sources made available by central and local authorities.

Few studies have been conducted in Terai districts (Nepal), related to changes in forest cover. For example, Panta (2008) conducted a study in Chitwan district (inner Terai) during 1976 and 2001 reporting a loss of $15 \%$ forest cover at an annual rate of decline of about $0.6 \%$. Similarly, another study conducted in another district (Bara, Terai), also revealed a forest loss of $11.56 \%$ at an annual rate of $0.72 \%$ from 1989 to 2005 (Bhattarai, 2007). The present study also proves forest cover loss during 19902011. Although the management of forest resources through a community forestry program of the Ministry of Forest and Soil Conservation is contributing in increasing forest cover, more efforts must be made to recover the lost forest in inner Terai and Terai districts.

\section{Conclusion}

This research uses the supervised approach to assess the changes in forest cover of the inner Terai districts (Dang district) of Nepal based on time series Landsat data. Analysis of forest cover change over time and of the factors driving the change is important for management of the remaining natural resources in the study area. It demonstrates that forest cover seems to be disappearing at the rate of $0.21 \%$ per year and the dense forest is being changed into the sparse forest at the rate of $0.12 \%$ per year. Most forest cover changes occurred in the areas close to the district borders, in the mid, and the southwestern part of the district. Forest encroachment can be considered as the main factor of deforestation and degradation in the study area, as driven by the high rate of population increase. Although the total forest area has decreased between 1990 and 2011, the total vegetative cover (i.e., shrubs, grasses, weeds and other inferior regeneration) appears to have increased. This study can be further improved by considering other time series of imagery and more methods of change detection analysis such as object based classification and fuzzy classification. The study recommends further assessment of the driving factors for better explanation of the impact of these factors on forest cover change. The study provides useful direction for future monitoring efforts to support management policy and initiatives taken by the Government of Nepal like Climate Change and REDD+ Programme. 


\section{References}

Baumann, M., Ozdogan, M., Wolter, P., Krylov, A., Vladimirova, N. and Radeloff, $V$. 2014. Landsat Remote Sensing of Forest Windfall Disturbance. Remote Sensing of Environment, 143: 171179.

Bhattarai, K. 2007. Evaluating Land Use and Forest Cover Change in Bara district. Journal of Human Ecology, 36 (1): 81-95.

Brampton, J. and Cammaert, B. 2007. How Can Timber Rents Better Contribute to Poverty Reduction Through Community Forestry in the Terai Region of Nepal? Journal of Forest and Livelihood, 6(1): 28-47.

Butt, A., Shabbir, R., Ahmad, S. and Aziz, N. 2015. Land Use Change Mapping and Analysis Using Remote Sensing and GIS: A Case Study of Simly Watershed, Islamabad, Pakistan. The Egyptian Journal of Remote Sensing and Space Science, 18(2): 251-259.

CBS. 2012. Statistical Year Book of Nepal. Kathmandu, Nepal: Central Bureau of Statistics, Government of Nepal.

Chasmer, L., Hopkinson, C., Veness, T., Quinton, W. and Baltzer, J. 2014. A Decisiontree Classification for Low-lying Complex Land. Remote Sensing of Environment, 143: 73-84.

Churches, C., Wampler, P., Sun, W. and Smith, A. 2014. Evaluation of Forest Cover Estimates for Haiti Using Supervised Classification of Landsat Data. International Journal of Applied Earth Observation and Geoinformation, 30: 203-216.
DFSP. 2012. Final District Forestry Sector Plan for Dang district. Kathmandu, Nepal. Department of Forest, Ministry of Forest and Soil Conservation.

DoF. 2005. Forest Cover Change Analysis of the Terai Districts, 1990/91-2000/01. Department of Forest, Ministry of Forest and Soil Conservation. Kathmandu, Nepal.

Dronova, I., Gong, P., Wang, L. and Zhong, L. 2015. Mapping Dynamic Cover Types in a Large Seasonally Flooded Wetland Using Extended. Remote Sensing of Environment, 158: 193-206.

El Baroudy, A. and Moghanm, F. 2014. Combined Use of Remote Sensing and GIS for Degradation Risk Assessment in Some Soils of the Northern Nile Delta, Egypt. The Egyptian Journal of Remote Sensing and Space Science, 17(1): 77-85.

FAO. 2015. Global Forest Resources. Rome, Italy. Food and Agriculture Organization of the United Nations.

FAO. 2000. On Definition of Forests and Forests Change. Food and Agriculture Organization of the United Nations.

FRA.2014.Terai Forests of Nepal (2010-2012). Forest Resource Assessment Nepal Project/ Department of Forest Research and Survey. Babarmahal, Kathmandu.

Goldsmith, F. 1998. Tropical Rain Forest. London: Champion and Hall.

Huang, S. and Siegert, F. 2006. Land Cover Classification Optimized to Detect Areas at Risk of Desertification in North China Based on Spot 
Vegetation Imagery. Journal of Arid Environments, 67(2): 308-327.

Iqbal, M. and Khan, I. 2014. Spatiotemporal Land Use Land Cover Change Analysis and Erosion Risk Mapping of Azad Jammu and Kashmir, Pakistan. The Egyptian Journal of Remote Sensing and Space Science, 17(2): 209-229.

Jayanth, J., Koliwad, S. and Kumar, T. 2015. Classification of Remote Sensed Data Using Artificial Bee Colony Algorithm. The Egyptian Journal of Remote Sensing and Space Science, 18(1): 119-126.

Naqvi, H., Siddiqui, L., Devi, L. and Siddiqui, M. 2014. Landscape Transformation Analysis Employing Compound Interest Formula in the Nun Nadi Watershed, India. The Egyptian Journal of Remote Sensing and Space Science, 17(2): 149-157.

NBS. 2002. Nepal Biodiversity Strategy (NBS). Ministry of Forests and Soil Conservation, His Majesty's Government of Nepal.

Panta, M. 2008. Temporal Mapping of Deforestation and Forest Degradation in Nepal.
Rawat, J., Biswas, V. and Kumar, M. 2015. Changes in Land use/Cover Using Geospatial Techniques: A Case Study of Ramnagar Town Area, District Nainital, Uttarakhand, India. The Egyptian Journal of Remote Sensing and Space Science, 16 (1): 111-117.

Weng, Q. 2001. A remote Sensing-GIS Evaluation of Urban Expansion and its Impact on Surface Temperature in the Zhujiang Delta Southern China. International Journal of Remote Sensing, 22(10): 1999-2014.

Yiran, G., Kusimi, J. and Kufogbe, S. 2012. A Synthesis of Remote Sensing and Local Knowledge Approaches in Land Degradation Assessment in the Bawku East District, Ghana. International Journal of Applied Earth Observation and Geoinformation, 14(1): 204-213.

Zhang, X., Delu, P., Chen, J., Jhan, Y. and Mao, Z. 2013. Using Long Time Series of Landsat Data to Monitor Impervious Surface Dynamics: A Case Study in the Zhoushan Islands. Journal of Applied Remote Sensing, 7(1), 073515 . 